\title{
Reflections on the Development of English Major in Higher Vocational Colleges Based on Social Needs
}

\author{
Shanshan Ju \\ Jiangxi Technical College of Manufacturing 330095, China
}

Keywords: higher vocational colleges; English major; social needs; development

\begin{abstract}
Higher vocational teaching aims to cultivate high-quality and skilled talents for the society. The development of English major should also take social needs as the starting point, regard market as the guidance and cultivate English major talents with more competitiveness edges. This paper firstly analyzes the importance of English major development in higher vocational colleges based on social needs, then, in combination with discussion of problems which exist in English major teaching in the above colleges, several methods are proposed based on social needs for developing higher vocational English major.

With the development of economic and cultural globalization, foreign commercial exchange of our country tends to be more frequent. More and more foreign enterprises enter China, leading to gradually increasing needs for practical English talents from various industries in the society. At the same time, with the continuous development of higher vocational education, English has become one of the majors with largest enrollment scale in higher vocational colleges. While with the change of market environment, graduates of English majors in higher vocational colleges are confronting more fierce competition. Problem that how to change the current talents cultivation status of English major, then promote English teaching quality in further needs to be solved urgently.
\end{abstract}

\section{Importance of English Major Development in Higher Vocational Colleges Based on Social Needs}

With the development of economic globalization and the proposition of national strategy of "The Belt and Road”, social needs for English talents are increasing, especially the interdisciplinary talents of English major, which also provide good opportunities for higher vocational colleges and English major to develop. Meanwhile, due to the influence of overall development trend of domestic economy, the phenomena of "talent surplus", "difficult employment of undergraduates" in the society has taken place gradually around us. Higher vocational undergraduates majored in English confront extremely fierce employment competition and even many English related positions have been occupied by undergraduates and postgraduates whose majors are not English. From the perspective of higher vocational characteristics, their teaching targets the cultivation of high-quality and skilled talents in the fields of production, management, construction and so on. Different from undergraduate universities, higher vocational colleges are attached with strong professional characteristics, aiming to cultivate practical talents and focusing to serve the community as well as local economic development. Therefore, the higher vocational teaching of English major must pay attention to students' development of professional skills and cultivate practical as well as skilled talents which are needed by the social development. It is quite urgent to shorten the distance between social needs and higher vocational talents cultivation by combining current social needs sufficiently. In this way, it is very efficient to help students become English practical talents. At the same time, it is also necessary to highlight major features, combine teaching with major cultivation objectives and then keep education in line with social needs. Thus, the internal English learning driving force of higher vocational students will be fully stimulated which can make them realize the importance of study, engage in mastering more professional knowledge and improve their employment competitiveness in further. ${ }^{[1]}$ 


\section{Analysis of Development Problems of English Major Teaching in Higher Vocational Colleges}

At present, there are many problems existing in English major teaching of higher vocational colleges like outdated teaching mode, low teaching efficiency, students' lack of language application ability and so on. An analysis of these problems will be carried out in the following part.

English major of higher vocational colleges has experienced a rapid development in recent years. Many colleges have set up related majors such as Business English, Applied English and Tourism English. However, in the view of current status, due to undefined teaching objectives, the teaching of English major in higher vocational colleges has become a concentrated version of English teaching in undergraduate universities, attaching too much importance to fundamental knowledge, but neglecting to some degree the cultivation of language application ability. Moreover, there are certain differences in learning initiative and leaning ability between higher vocational students and undergraduate students, which make the former lack English learning motivation. During teaching, it also can be found that many students are poor in reading ability of application documents, weak in translation and incompetent in oral communication. A lot of students are not able to interact in written language, use accurate words or express their real meaning.

Many higher vocational colleges take traditional classroom lecture mode. This kind of indoctrination leads students to be dependent on teachers and independent to think as well as practice. Besides, higher vocational students are comparatively deficient in English fundamental level and weak in learning initiative. If there is not enough guidance, it will be difficult to stimulate students' English learning interests. During English practice, it is not difficult to discover that in order to cope with examinations and related registration exams, a lot of students have to learn English. They don't realize the importance of English to their future employment. In addition, modern teaching technology is in a rapid development and the new media teaching is getting popular in universities, while all of them are not fully applied in English major teaching in higher vocational colleges. In daily teaching, there are too much teachers' teaching and theories, but few interaction and multimedia application. Therefore, the teaching effectiveness is not satisfactory. ${ }^{[2]}$

The talents cultivation in higher vocational colleges stresses professionalism, practicality as well as a match between majors and positions. However, in the English teaching system, its application and professional characteristics are not reflected sufficiently. Main courses are not prominent and fail to reflect professions and social needs. For example, as for Applied English major, writing and oral classes are less than extensive and intensive reading classes. Listening. Besides, speaking, reading, writing and translating cover the main leaning contents during higher vocational education stage. The ratio between professional theoretical courses and practical courses is 7 to 3 which doesn't meet the requirements of curriculum setting as well as not conducive to the cultivation of skilled and practical English talents. English actual application abilities like oral English are quite important for higher vocational graduates. While most students regard Public English Tests as the main goals, emphasizing written tests but ignoring the practice of abilities like oral English. Colleges' assessment criteria also lay stress on written tests and passing rate of public English tests. So from the long-term perspective, although regarding public English tests as the main objective of English learning can to a certain extent enhance students' English level, it is still difficult to improve their English practical competence. ${ }^{[3]}$ Simultaneously, the teaching pertinence is not strong and fails to match students' future position needs. Besides, unclear practical teaching objectives, a lack of training bases and students' deficient practical abilities also lead to the phenomenon that part of graduates fail to meet the social requirements for English major talents.

Most English teachers of higher vocational colleges majored in language who are excellent in English teaching but weak in professional skills knowledge. Some of them do not have the practical experience in enterprises while most professional knowledge are achieved through short-term training. Therefore, their teaching usually puts attention on the explanation of English language knowledge, but overlooks professional skills knowledge. Besides, due to the restriction of various factors such as the development of higher vocational colleges, English teachers stress teaching much more than scientific research. Teachers always bear heavy teaching tasks, so they have few chances for advanced studies which affect the development of their professional abilities, then in 
further lead to the hysteretic construction of English teaching faculty and make them fail to accommodate to the actual needs of English teaching.

\section{Development Methods of English Major in Higher Vocational Colleges Based on Social Needs}

The development of English major in higher vocational colleges must closely relate to social market dynamics and its talent cultivation mode should be defined based on social needs. Its talents cultivation is characterized by certain regional features, making contributions to the regional production, construction, management and so on. Therefore, the development of English major construction in higher vocational colleges should make its market positioning clear, strengthen the in-depth investigation of regional market situations, master the market's actual needs for talents and understand the truth that higher vocational talents majoring in English are able to bring changes to regional development. It is feasible to custom-tailor a scientific talents cultivation judgment by combining needs orientation and regional situation of social economy development, directing the reformation of English major teaching.

In the practice of teaching, it is suggested to fully make use of teaching technologies such as multimedia and network. These will update and optimize the traditional English teaching mode, convert teacher-centered mode into students' autonomous learning mode. As for teaching methods, it is also recommended to actively apply hierarchical teaching approach, 3T teaching approach, and communicative teaching approach and so on. Teachers are able to flexibly apply these approaches based on the actual teaching situations. For example, the communicative approach can be used to teach students to advocate a fusion between study and daily interactions and then achieve the improvement of practical application ability of English knowledge. Simultaneously, the usage of network in teaching also can activate students' interests and stimulate their initiatives in English learning during life activities. It is able to promote interactive feedback between teachers and students, make students more good at finding and dealing problems in study and in further master knowledge more efficiently. For example, teaching forms like micro class and Mooc will guide students to make use of internet to do fragmentation learning, master the latest major dynamics, strengthen communication between teachers and students as well as students and students, and then construct a new student-centered teaching mode. Moreover, the rapid development of economy with the continuous change of society also brings diversification to teaching contents. The English teaching of higher vocational colleges needs to update and supplement contents in time, make teaching more practical and contemporary. ${ }^{[4]}$ Specifically, teachers are required to supplement applicable and new knowledge to daily teaching which will not only make students master language knowledge, but also know to some extent the social changes and cultural information etc. , expanding their visual field and improving the ability to adapt to society.

The most direct and efficient method to construct English major in higher vocational colleges based on social needs is "a combination between learning and practice". It is feasible to achieve cooperation between colleges and enterprises, cultivating English talents urgently needed by the society. The curriculum construction of higher vocational colleges should pay attention to the practical courses. It is advised to design courses by taking the actual working tasks of enterprises into consideration, think highly of the cultivation of factual competence and professional qualities, then construct an integrated curriculum system which involves theories and practice. In addition, the cooperation between colleges and enterprises should be enhanced. Higher vocational colleges can take an "order" cultivation mode which means an in-depth cooperation with enterprises, a design of appropriate major teaching programs according to enterprises' specific needs, an update of teaching modes and the satisfaction of enterprises' and market's needs. These can be achieved through the construction of training and practice bases. These bases will provide a dynamic and real working environment and enable to create more practical chances for students. For example, colleges can hold local activities like expositions for students and arrange them to take part in through which students are able to improve their abilities like interpretation and translation. It is also suggested to set up foreign trade translation studios with enterprises. These will enable students to undertake foreign trade related business in the real working environment thus continuously 
improve professional competence. At the same time, through seamless connection with workplace environment, colleges will help students promote their employability and employment competitiveness.

For English teachers, in addition to the solid professional knowledge and skills, they are also required to grasp development dynamics of English major and be able to put forward constructive suggestions for social applicability of English major, curriculum rationality and practical teaching development. Therefore, higher vocational colleges should strengthen the cultivation of double-professional teaching faculty by arranging teachers with excellent professional qualifications to enterprises for practice. In this way, it is effective to train teachers' professional competence and lead them to combine theories and practice in teaching. Besides, it is also feasible to hire workers of enterprises as part-time English teachers who will bring professional and socialized modes and contents to English teaching, improve teaching faculty level and make English teaching more practical. ${ }^{[5]}$ In addition, higher vocational colleges should support teachers to study in other colleges and do advanced study in order to improve theoretical level as well as practical ability. Regular training can be launched. In the training, education professionals can be invited to do lecture reports. These reports are quite conducive to lead teaching faculty to master the latest academic dynamics and research results, enhance comprehensively teachers' teaching practical and research level, promote their overall quality and then speed up teaching development of English major.

\section{Conclusion}

In a word, English major teaching in higher vocational colleges have made great achievements in recent years. However, under new circumstances, they also have ushered new development opportunities as well as challenges. Confronting new employment environment and trends, in order to achieve the development of English major construction, colleges should be social needs orientated, actively explore effective teaching modes, enrich teaching methods and contents, strengthen practical teaching as well as teaching faculty construction and then construct a good English major development system, providing more excellent and skilled English talents for the social development.

\section{References}

[1]Chen Xiaojuan. The Analysis of Demands for Applied English Major Talents Based on Regional Economy Development [J]. Journal of Hubei Correspondence University, 2016 (13): 125-126.

[2]Ouyang Wenping. Main Problems Existing in Post Competence Cultivation of Business English Major in Higher Vocational Colleges and Countermeasures [J]. Modern Economic Information, 2016 (14): 29.

[3]Yu Ya, Chen Pinrong. The Construction of Practical Teaching System from the Perspective of Demand Analysis [J]. Journal of Kaifeng Institute of Education, 2017 ( 7): 192-193.

[4]Guo Tingting, Huang Qingqiang. An Application Research on the Optimization of Applied English Major Curriculum System in Higher Vocational Colleges [J]. New Course, 2016 ( 3 ): 19.

[5]Chen Pinrong. The Construction of Industry Needs Model of Business English Major Development in Higher Vocational Colleges [J]. Journal of Hunan University of Humanities, Science and Technology, 2017 (1): 121-124. 